\section{(6) OPEN ACCESS}

\title{
Measuring changes in the illicit cigarette market using government revenue data: the example of South Africa
}

\author{
Corné van Walbeek
}

\section{Correspondence to}

Professor Corné van Walbeek, School of Economics Building, Middle Campus, University of Cape Town, Rondebosch,

7701, South Africa; cwalbeek@gmail.com

Received 31 May 2013 Revised 20 November 2013 Accepted 10 December 2013 Published Online First 15 January 2014

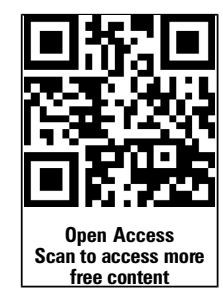

\begin{tabular}{l}
\hline To cite: van Walbeek C. \\
Tob Control 2014;23: \\
e69-e74. \\
\hline
\end{tabular}

\begin{abstract}
Background The tobacco industry claims that illicit trade in cigarettes has increased sharply since the 1990s and that government has lost substantial tax revenue. Objectives (1) To determine whether cigarette excise tax revenue has been below budget in recent years, compared with previous decades. (2) To determine trends in the size of the illicit market since 1995.

Methods For (1), mean percentage errors and root mean square percentage errors were calculated for budget revenue deviation for three products (cigarettes, beer and spirits), for various subperiods. For (2), predicted changes in total consumption, using actual cigarette price and GDP changes and previously published price and income elasticity estimates, were calculated and compared with changes in tax-paid consumption.

Results Cigarette excise revenues were $0.7 \%$ below budget for 2000-2012 on average, compared with 3.0\% below budget for beer and $4.7 \%$ below budget for spirits. There is no evidence that illicit trade in cigarettes in South Africa increased between 2002 and 2009. There is a substantial increase in illicit trade in 2010, probably peaking in 2011. In 2012 tax-paid consumption of cigarettes increased $2.6 \%$, implying that the illicit market share decreased an estimated 0.6 percentage points. Conclusions Other than in 2010, there is no evidence that illicit trade is significantly undermining government revenue. Claims that illicit trade has consistently increased over the past 15 years, and has continued its sharp increase since 2010, are not supported.
\end{abstract}

\section{INTRODUCTION}

South Africa was one of the first middle-income countries to adopt a strong tobacco control policy. The policy was initiated in the early 1990s, but was given much impetus in 1994 after the first democratic elections. It was anchored on rapid excise tax increases and strong legislation. Primarily because of excise tax-induced price increases, aggregate cigarette consumption in South Africa decreased by a third between 1994 and 2004, after which it stabilised. $^{12}$

The tobacco industry opposed the tax increases from the start. The standard response was that tax increases would encourage the illicit trade in cigarettes. Illicit trade includes large-scale cigarette smuggling (typically run by criminal syndicates, where no tax is paid altogether), small-scale smuggling or bootlegging (where individuals typically buy cigarettes in low-tax countries and bring modest quantities into the high-tax country for resale), illicit manufacturing (where production breaches taxation or other laws) and counterfeiting (where the product bears a trademark without the consent of the owner of the trademark). ${ }^{3}$

Illicit trade indeed undermines some of the benefits of an excise tax increase. Government would lose revenue. Some smokers, who may otherwise have quit smoking, would continue their habit by buying cheaper illicit cigarettes. Also, if illicit trade takes the form of counterfeiting, established firms would have their brands and market shares unfairly undermined. Since 1996, when the chief executive officer of the largest cigarette manufacturer wrote an open letter to the Minister of Health in which he warned her of the threat of cigarette smuggling, ${ }^{4}$ the industry has argued that excise tax increases stimulate the illicit market. The South African fiscal authorities have apparently bought into this argument. Since 2004 the excise tax structure and rate (expressed as a percentage of the retail price) has remained unchanged. Despite appeals from the Ministry of Health and civil society to increase the excise tax, officials at the Treasury defend the current system on the grounds that it works well for all parties. ${ }^{5}$

Within this context, the paper investigates two claims: (1) that increases in illicit cigarette trade significantly undermine the Treasury's excise tax revenue and (2) that there has been a sharp increase in the illicit market in recent years. To investigate the first claim, the paper compares actual excise tax revenue from cigarettes to budgeted excise tax revenue over a long time period. To investigate the second claim, changes in tax-paid cigarette consumption are compared with predicted changes in total cigarette consumption for the period after 1995. The predicted changes in cigarette consumption are based on well-established relationships between cigarette consumption and cigarette prices and income. If the actual change deviates significantly from the predicted change, this would be congruent with a change in the illicit market size.

\section{METHOD}

To analyse the Treasury's ability to accurately budget for excise revenue the paper uses two summary statistics often used in analysing the accuracy of forecasts, namely the mean percentage error (MPE) and the root mean squared percentage error (RMSPE). ${ }^{6}$ The MPE indicates whether forecasts/ budgets are consistently too high or too low, compared with the outcome value. The MPE is defined as $\frac{1}{\mathrm{n}} \sum_{\mathrm{i}=1}^{\mathrm{n}}\left[\left(\mathrm{A}_{\mathrm{i}}-\mathrm{B}_{\mathrm{i}}\right) / \mathrm{B}_{\mathrm{i}} \times 100\right]$ where $A_{i}$ is actual tax

revenue, $B_{i}$ is budgeted tax revenue and $n$ is the number of years for which the summary statistic is 
calculated. A negative or increasingly negative MPE value is consistent with an increase in illicit trade.

Should illicit trade become structural, it seems reasonable that the Treasury would take the illicit trade into account and budget for lower legal (ie, tax-paid) cigarette sales. Budgeting becomes more difficult and one would expect the deviations, on average, to become larger. The RMSPE considers the squared deviations from the budgeted tax revenue. The RMSPE is defined as $\sqrt{\frac{1}{n} \sum_{i=1}^{n}\left[\left(A_{i}-B_{i} / B_{i}\right) \times 100\right]^{2}}$. The RMSPE is a measure of dispersion, similar in interpretation to the standard deviation as a descriptive statistic.

By design, the MPE and the RMSPE consider deviations from budget for relatively long periods of time (typically at least 5 years). Large once-off deviations, possibly indicating a sudden spike in illicit trade, may not be captured by the MPE and/or the RMSPE. To determine whether there have been sizeable once-off deviations we graphically analyse the revenue deviations for the period since 1990 .

To provide context and comparison, the study considers beer and spirits, as well as cigarettes. All three products are subject to a specific tax (ie, a tax based on quantity rather than value). Budgeted and actual excise tax revenues received are independent of pricing decisions. Since beer and cigarette producers are nearmonopolies, and the supply of spirits is also very concentrated, the Treasury's excise revenue budgeting processes and budgeting methodologies for these three products are likely to be similar. Thus the MPE and RMSPE for these three products should be comparable.

The actual growth in tax-paid cigarette consumption is compared with the predicted growth of total (ie, legal and illicit) cigarette consumption. To the extent that tax-paid cigarette consumption decreases by more than the predicted decrease in total cigarette consumption, this would be a rough indication of the growth of the illicit market.

\section{DATA}

Data on budgeted and actual excise revenue for beer, spirits and 'cigarettes and cigarette tobacco' were taken from individual Auditor-General reports, published annually since $1910 .^{8}$ For the period after 1997 the data were taken from statistical tables in the Treasury's Budget Review. ${ }^{2}$ 'Cigarettes and cigarette tobacco' are referred to as 'cigarettes' henceforth in this paper, since cigarette tobacco comprises a negligible proportion of the combined category.
The financial year for the government is from April to March. The data is presented for financial years, removing any possible distortion had the data been converted to calendar year. However, for ease of reading, the years are not presented as $t / t+1$ but rather as $t$. GDP data are derived from the South African Reserve Bank's (SARB) database, and consider the second quarter to the first quarter of the following year, that is, they coincide with the financial year. ${ }^{9}$ Values for the real price of cigarettes were obtained by dividing the price index for tobacco (as it is recorded in the calculation of the Consumer Price Index (CPI)) with the CPI of all goods and services, based on Statistics South Africa's monthly P0141 publication. ${ }^{10}$ The monthly year-on-year growth rates in the real price were averaged over the financial year.

Budgeted and actual excisable quantities were obtained by dividing the budgeted and actual revenue by the relevant excise tax.

\section{RESULTS}

\section{Mean percentage error}

The MPEs are shown in columns (1) to (3) in table 1 . For the postwar period (1945-2012) actual excise revenue from cigarettes were, on average, exactly on budget, compared with $1.7 \%$ above budget for beer and $1.3 \%$ below budget for spirits. During the 1960s, 1970s and 1980s beer excise revenue was generally well above budget, but in the past 13 years (2000-2012) beer revenue was below budget by an average of $3.0 \%$. Spirits revenue has been below budget for most years since 1970, but the shortfalls have increased in the $1990 \mathrm{~s}$ (average of 2.9\% underbudget) and especially since 2000 (average of $4.7 \%$ underbudget). Cigarette excise revenue has been remarkably close to budget throughout the postwar period.

In contrast to beer and spirits excise revenue, cigarette excise revenue has been only $0.7 \%$ below budget in the 2000-2012 period. In the shorter and recession-effected 2005-2012 period cigarette excise revenue was, on average, $2.6 \%$ below the budgeted revenues, compared with average shortfalls of $2.2 \%$ and $5.1 \%$ for beer and spirits, respectively. For the 4-year period 2009-2012 cigarette excise revenue was 6.5\% below budget, compared with $0.3 \%$ below budget for beer and $1.0 \%$ above budget for spirits. This recent weak performance of cigarette excise revenue is problematic and is discussed in more detail below.

Table 1 Mean percentage error (MPE) and root mean square percentage error (RMSPE) of the deviation from budget revenue

\begin{tabular}{|c|c|c|c|c|c|c|c|}
\hline \multirow[b]{2}{*}{ Time period (financial years) } & \multirow[b]{2}{*}{ Number of years } & \multicolumn{3}{|l|}{ MPE } & \multicolumn{3}{|l|}{ RMSPE } \\
\hline & & Beer (1) & Spirits (2) & Cigarettes (3) & Beer (4) & Spirits (5) & Cigarettes (6) \\
\hline 1910 to 1944 (pre-WW2) & 35 & 5.0 & 2.7 & $6.4^{*}$ & 17.4 & 15.3 & $12.8^{*}$ \\
\hline 1945 to 2012 (post-WW2) & 68 & 1.7 & -1.3 & 0.0 & 8.8 & 10.2 & 5.3 \\
\hline 1945 to 1959 & 15 & -1.3 & -0.2 & -0.1 & 7.3 & 9.1 & 5.0 \\
\hline 1960 to 1969 & 10 & 5.4 & 3.6 & 0.3 & 12.4 & 4.9 & 4.4 \\
\hline 1970 to 1979 & 10 & 4.3 & -2.8 & 1.1 & 10.4 & 14.0 & 4.8 \\
\hline 1980 to 1989 & 10 & 6.0 & -0.3 & 0.7 & 9.9 & 10.5 & 3.4 \\
\hline 1990 to 1999 & 10 & 1.7 & -2.9 & -0.9 & 6.3 & 9.0 & 8.5 \\
\hline 2000 to 2012 & 13 & -3.0 & -4.7 & -0.7 & 6.2 & 11.6 & 4.5 \\
\hline 2005 to 2012 & 8 & -2.2 & -5.1 & -2.6 & 6.0 & 11.3 & 5.4 \\
\hline 2009 to 2012 & 4 & -0.3 & 1.0 & -6.5 & 7.1 & 10.2 & 7.2 \\
\hline
\end{tabular}




\section{Root mean square percentage errors}

RMSPEs are presented in the columns (4) through (6) in table 1 for beer, spirits and cigarettes, respectively. The RMSPEs quantify the magnitude of the deviation from budgeted revenue, irrespective of whether it is positive or negative. RMSPEs in the post World War II period (1945-2012) are much lower than in the pre World War II period (1910-1944) for all three products. For the postwar period as a whole the RMSPE for cigarette excise revenue was $5.3 \%$, compared with $8.8 \%$ for beer and $10.2 \%$ for spirits.

Of particular relevance for the current study are the magnitudes of the RMSPEs for the period in which illicit trade is alleged to have increased. One would expect an increase in illicit trade to increase the RMSPE, because illicit trade increases uncertainty in the budgeting process. Previously stable relationships between tax, price and consumption break down and Treasury officials have to guess, rather than plan for, the excise revenue, resulting in much larger deviations. The RMSPE for cigarette excise revenue for $2000-2012$ is $4.5 \%$, substantially lower than the $8.5 \%$ for $1990-1999$, and also lower than the $5.3 \%$ for the postwar period. For the shorter 8-year period 2005-2012, the RMSPE for cigarette revenue was 5.4\%, practically the same as the postwar RMSPE of 5.3\%. For the very short 4-year period 2009-2012 the RMSPE is 7.2\%, somewhat higher than the postwar value, but still lower than the 19901999 period.

In contrast, the RMSPE for spirits excise revenue for 20002012 was $11.6 \%$, much higher than that of cigarettes $(4.5 \%)$ and also higher than the postwar RMSPE of $10.2 \%$. For beer excise revenue the RMSPE was $6.2 \%$. For the shorter 8 -year period (2005-2012) and the even shorter 4-year period 20092012 the RMSPEs of beer and spirits excise revenue was similar to that of cigarettes.

The long-term analysis clearly shows that cigarette excise revenue has been more predictable than the revenues from beer and spirits in all subperiods in the 21st century. There is no statistical evidence that the alleged increase in illicit trade in cigarettes has had a substantial negative impact on the predictability of cigarette excise revenue. However, the MPE and the RMSPE indicate that cigarette excise revenue has not been as predictable in the past 4 years (2009-2012) as in the preceding period (2000-2008). This requires further analysis, presented below.

\section{Graphical analysis}

The percentage deviations from budgeted excise revenue for beer, spirits and cigarettes are shown in figure 1 for 1990-2012. A positive value indicates that actual revenue was above budget, while a negative value indicates that actual revenue was below budget.

Three periods can be identified for cigarettes. In the first period (1990-1999) the budget deviations for cigarettes were substantial and broadly similar in magnitude to those of beer and spirits. During this period, and especially after 1994, the government substantially raised the excise tax on cigarettes. In fact, between 1994 and 1999 the excise tax per pack was increased by an average of $17 \%$ in real terms each year. Despite these large tax increases, which would have complicated the budgeting process, actual revenue was above budgeted revenue in three of the 6 years.

The 2000-2008 period was particularly stable and predictable in terms of cigarette excise revenue. Actual cigarette revenue exceeded budget by modest percentages in seven of the 9 years. In contrast, actual tax revenues for beer and spirits were typically below budget over this period.

Despite the lack of evidence from the Treasury's revenue data, the Tobacco Institute of Southern Africa (TISA) vehemently claimed that the illicit market had increased from being practically non-existent in the mid-1990s to $20 \%$ of the total market in $2006 .^{11}$ TISA kept to this number for 5 years. TISA claimed that the share of illicit trade had increased to $26 \%$ in 2011 , and to $30 \%$ in $2012 .^{12}$

A structural break, alluded to in the discussion of table 1, occurred in 2009. Actual cigarette excise revenues have been below budget in each of the 4 years between 2009 and 2012, suggesting that over this period the illicit market share has increased. For these 4 years, budgeted tobacco tax revenue was $6.5 \%$ below budget on average. The shortfall of actual tobacco tax revenues (relative to budget) peaked at $11.5 \%$ in 2010 , but improved to shortfalls of $4.1 \%$ in 2011 and $6.1 \%$ in 2012.

\section{Simulation analysis based on budgeted and actual quantities}

Since the excise taxes on cigarettes are levied as a specific tax, budgeted (and actual) consumption is easily derived by dividing the budgeted (and actual) excise revenue by the budgeted tax per unit. For example, in fiscal year 2012 the Treasury's
Figure 1 Budget deviations for beer, spirits and cigarettes, financial years 1990-2012. Source: Author's calculations based on Auditor-General (various years) and Budget Reviews (various years).

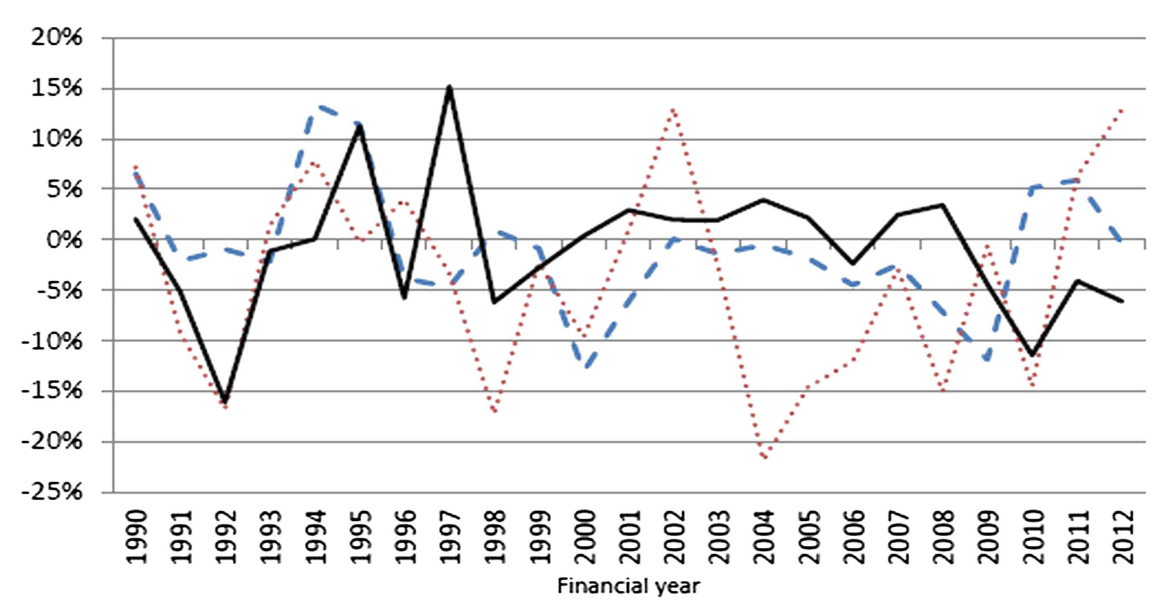

- - Beer ...... Spirits Cigarettes 
budget for cigarette revenues was 11735 million rand (about US\$1676 million), based on an excise tax of 10.32 rand (about US\$1.47) per pack. Actual revenue was 11057 million rand. Thus the budgeted quantity was 1137 million packs $(=11$ $735 / 10.32)$ and the actual quantity was 1071 million packs (=11 057/10.32).

In the simulation, one compares the actual growth in consumption of legal cigarettes with the predicted growth in total cigarette consumption (ie, legal and illicit). If actual consumption growth of tax-paid cigarettes is less than the predicted growth in total cigarette consumption (and ignoring random variations), I infer that the illicit market is becoming larger by approximately the difference between the two growth rates. For example, if tax-paid cigarette consumption decreases by $5 \%$, and predicted consumption decreases by only $2 \%$, this would imply that the illicit market increases by approximately three percentage points of the total market.

The predicted growth rate in total cigarette consumption is crucial in determining changes in the size of the illicit market. The literature (South African and international) clearly indicates that the two main determinants of cigarette consumption are income and cigarette prices. ${ }^{1}{ }^{13-18}$ South African estimates of price and income elasticities of demand are all based on time series data, and with one exception ${ }^{18}$ consider the period from 1970 to somewhere between $1989^{14}$ and $2002 .^{1}$ The statistical fit for these regression models is very high, with $\mathrm{R}^{2}$ values typically above 0.80 and in some cases above 0.95 . The price elasticity estimates for South Africa are all in the inelastic range and centre on about -0.6 . The income elasticity estimates are also in the inelastic region and centre on about 0.6 , in line with international experience. ${ }^{13}$ In the simulation below a price elasticity of -0.6 and an income elasticity of 0.6 is assumed. To test the sensitivity of the results to the choice of price and income elasticity value, I present the minimum and maximum outcomes for four different price $\left(E_{P}\right)$ and income $\left(E_{Y}\right)$ elasticities, namely (1) $E_{P}=-0.4$ and
$\mathrm{E}_{\mathrm{Y}}=-0.4 ;$ (2) $\mathrm{E}_{\mathrm{P}}=-0.4$ and $\mathrm{E}_{\mathrm{Y}}=-0.8$; (3) $\mathrm{E}_{\mathrm{P}}=-0.8$ and $\mathrm{E}_{\mathrm{Y}}=$ -0.4 ; and (4) $E_{P}=-0.8$ and $E_{Y}=-0.8$. These elasticity values are in the typical range for low-income and middle-income countries. ${ }^{13}$ For better readability, the ensuing discussion will focus on the results based on $\mathrm{E}_{\mathrm{P}}=-0.6$ and $\mathrm{E}_{\mathrm{Y}}=0.6$ only.

Percentage changes in budgeted and actual quantity, relative to the previous year's actual quantity, are shown in columns 1 and 2 in table 2 . The simulation exercise is presented for the period 1995 onwards. Changes in the average real price, as discussed in the Data section, are shown in column 3. The survey includes some very low price (and possibly illicit) brands. Changes in real GDP are shown in column 4 . The predicted quantity change, shown in column 5 , is the growth in the real price, multiplied by the price elasticity $\left(E_{P}=-0.6\right)$, plus the growth in real GDP, multiplied by the income elasticity $\left(E_{Y}=0.6\right)$. The numbers in parentheses are the minimum and maximum percentage changes in predicted quantity, based on the four scenarios mentioned in the previous paragraph. The change in the illicit market share is the difference between the predicted change in the quantity (column 5) and the actual change (column 2).

While one might be tempted to estimate the size of the illicit market as the sum of the changes in the illicit market share, starting from some (arbitrary) base period, this is not advised. The reason is that aberrations and/or random errors in previous years carry through to the present. The model aims to (approximately) quantify changes in the illicit market, and thus consider trend changes.

Colleagues at the University of Cape Town performed a survey of newspaper articles since 1990 using keywords 'cigarette', 'tobacco', 'tax', 'counterfeit cigarettes', 'smuggling', 'illegal trade' and 'illicit' and found that there were no reports or allegations of illicit trade before the mid-1990s. Within the constraints of random variation and a fairly parsimonious regression equation, table 2 indicates the following broad

Table 2 Budgeted, actual and predicted changes in cigarette consumption and in the illicit market share

\begin{tabular}{|c|c|c|c|c|c|c|}
\hline \multirow[b]{2}{*}{ Financial year } & \multicolumn{2}{|c|}{$\begin{array}{l}\text { Percentage change in } \\
\text { quantity }\end{array}$} & \multicolumn{2}{|c|}{ Percentage change } & \multicolumn{2}{|c|}{ Simulation: percentage changes } \\
\hline & Budgeted (1) & Actual (2) & Real price (3) & Real GDP (4) & Quantity (5) & Change in illicit market share (6) \\
\hline 1995 & -9.1 & 1.2 & 8.8 & 3.1 & $-3.4(-5.8 ;-1.0)$ & $-4.6(-7.0 ;-2.2)$ \\
\hline 1996 & -0.9 & -6.6 & 7.9 & 4.2 & $-2.2(-4.6 ; 0.2)$ & $4.4(2.0 ; 6.8)$ \\
\hline 1997 & -18.2 & -5.8 & 18.8 & 2.1 & $-10.0(-14.2 ;-5.8)$ & $-4.2(-8.4 ; 0.0)$ \\
\hline 1998 & 2.0 & -4.3 & 15.9 & 0.5 & $-9.3(-12.5 ;-6.0)$ & $-5.0(-8.2 ;-1.7)$ \\
\hline 1999 & -4.0 & -6.7 & 14.1 & 3.0 & $-6.7(-10.1 ;-3.2)$ & $0.0(-3.4 ; 3.5)$ \\
\hline 2000 & -5.2 & -4.9 & 5.4 & 4.2 & $-0.7(-2.6 ; 1.2)$ & $4.1(2.3 ; 6.1)$ \\
\hline 2001 & -5.9 & -3.1 & 4.7 & 2.7 & $-1.2(-2.7 ; 0.3)$ & $1.9(0.4 ; 3.4)$ \\
\hline 2002 & -5.5 & -3.7 & 0.5 & 3.6 & $1.9(1.0 ; 2.7)$ & $5.5(4.7 ; 6.4)$ \\
\hline 2003 & -1.2 & 0.7 & 7.8 & 3.1 & $-2.8(-5.0 ;-0.6)$ & $-3.5(-5.7 ;-1.3)$ \\
\hline 2004 & -6.0 & -2.3 & 6.7 & 5.0 & $-1.0(-3.4 ; 1.3)$ & $1.3(-1.1 ; 3.6)$ \\
\hline 2005 & -1.1 & 1.0 & 5.7 & 5.2 & $-0.3(-2.5 ; 1.9)$ & $-1.3(-3.5 ; 0.9)$ \\
\hline 2006 & 4.7 & 2.2 & 2.7 & 6.0 & $2.0(0.2 ; 3.7)$ & $-0.3(-2.0 ; 1.5)$ \\
\hline 2007 & -0.4 & 2.1 & 2.2 & 4.8 & $1.6(0.2 ; 3.0)$ & $-0.5(-1.9 ; 0.9)$ \\
\hline 2008 & -1.4 & 2.0 & -1.5 & 2.5 & $2.4(1.6 ; 3.2)$ & $0.4(-0.4 ; 1.2)$ \\
\hline 2009 & -1.7 & -6.0 & 9.1 & -0.8 & $-5.9(-7.9 ;-4.0)$ & $0.1(-1.9 ; 2.0)$ \\
\hline 2010 & -0.8 & -12.2 & 6.7 & 3.4 & $-2.0(-4.0 ; 0.0)$ & $10.2(8.2 ; 12.2)$ \\
\hline 2011 & 3.9 & -0.3 & -0.4 & 3.1 & $2.1(1.4 ; 2.8)$ & $2.5(1.7 ; 3.1)$ \\
\hline 2012 & 8.9 & 2.6 & -0.6 & 2.7 & $2.0(1.3 ; 2.6)$ & $-0.6(-1.3 ; 0.0)$ \\
\hline 2013 & 3.4 & & & & & \\
\hline
\end{tabular}

Source: Author's calculations based on Auditor-General (various years), Budget Reviews (various years), SARB Quarterly Bulletin (2013) and Statistics South Africa CPI (various years). 
trends. Between 1995 and 1998 the data were quite noisy. In the 3 years 2000-2002 tax-paid consumption decreased by substantially more than predicted by the model. While this would be congruent with an increase in illicit trade, the decrease in cigarette consumption could at least partially be explained by the legislation that came into effect in that period. Cigarette advertising was being phased out in 2000 and banned altogether in January 2001 and comprehensive smoke-free legislation became effective in July 2001.

In the subsequent 7-year period from 2003 to 2009 there is no evidence to suggest that the illicit market has grown. In fact, it is likely that the illicit market has shrunk during this period.

In 2010 there was a very definite spike in the illicit market, with its market share growing by about 10.2 (8.2 to 12.2 ) percentage points. However, the spike was not the start of a trend. In 2011 the illicit market increased only marginally and in 2012 it decreased by $0.6(-1.3$ to 0.0$)$ percentage points.

When the Budget Review was published in February 2013, the 'revised estimates' of revenue indicated that that cigarette consumption had increased by $6.3 \%$. The estimates were subsequently revised down such that consumption grew by a more modest $2.6 \%$. Although it is significantly less than the initial 'revised estimate', this is the highest growth in tax-paid cigarette consumption in more than 20 years. In a legislative and societal environment actively against smoking, and with anaemic economic growth, $2.6 \%$ growth in the legal market is most unlikely without a decrease in the illicit market.

The 2013 budget indicates that the Treasury is confident (or at least hopeful) of reducing the size of the illicit market, because the projected GDP growth rate of less than 3\% does not justify a growth in total cigarette consumption of $3.4 \%$. The only way that the Treasury can get close to this growth rate in legal consumption is if illicit consumption is reduced further.

\section{DISCUSSION}

There is a consensus in the literature that increasing the excise tax on tobacco products is the single most effective means of reducing tobacco use. ${ }^{13}$ Increasing the excise tax also increases government tax revenue. South Africa, like many other countries, has been extremely successful in reducing cigarette consumption and increasing government revenue by substantially raising the excise tax on tobacco products over a number of years.

An increase in the excise tax, and the associated retail price, increases the incentive to trade in illicit cigarettes. Should the illicit market expand sharply it will undermine the legal market and have detrimental fiscal consequences. However, an increased incentive for illicit trade does not mean that it translates into illicit trade. Numerous studies have shown that illicit trade is driven by a multitude of factors of which the excise tax is only one. ${ }^{19}$ In fact, many countries with very high excise rates have a much smaller illicit trade problem than countries with much lower excise taxes. ${ }^{20}$

The tobacco industry acknowledges that illicit trade may have other causes as well, but they emphasise the link between illicit trade and the excise tax. ${ }^{12}$ According to the tobacco industry the solution to illicit trade is clear: reduce, or, at the minimum, do not increase the excise tax. The tobacco industry has a vested interest in emphasising and exaggerating the magnitude and the growth of the illicit market. ${ }^{19}$

What is not said is that, in South Africa, the quantum of the excise tax is largely determined by the tobacco industry. Since 2004 the excise tax, which is levied as a specific tax, is set such that the total tax burden (ie, excise tax plus value-added tax) is $52 \%$ of the recommended retail price of the most popular brand. Between 1994 and 2003 the total tax burden was targeted at $50 \%$ of the recommended retail price. The system has been in place for nearly 20 years and has been consistently applied. The government passively adjusts the excise tax on an annual basis in order to keep the total tax burden at the set threshold. The industry controls the retail price of cigarettes through its control of the net-of-tax price. The absolute amount of the tax increases in response to retail price increases in the previous year.

The tobacco industry has been very effective at putting the threat of illicit trade in cigarettes in the minds of the public and Treasury officials. In 2010 TISA launched a public relations campaign, warning the public against smoking illicit cigarettes and linking illicit cigarettes with organised crime. ${ }^{21}$ In South Africa, with its very high rates of violent and organised crime, this campaign struck a sensitive chord with the public. Informal discussions between the author and officials at the Treasury indicate that the real or perceived threat of illicit trade prevents them from significantly increasing the excise tax. ${ }^{5}$

In a presentation by British American Tobacco (BAT) to the National Treasury in June 2012, BAT claimed that the illicit market had grown from $7.9 \%$ in 2008 to $10.4 \%$ in $2009,21 \%$ in 2010 and $26 \%$ in $2011 .^{22}$ Recently TISA indicated that the illicit market comprised $30 \%$ of the total cigarette market in 2012 and that it had risen toward 35\% in the first quarter of 2013. ${ }^{12}$ While the current study finds a substantial increase in the illicit market in 2010, there is no support for such large increases in 2011 and 2012. Also, the tobacco industry's illicit trade estimates suffer from time inconsistency. As far back as 2006 TISA claimed that illicit trade comprised $20 \%$ of the total cigarette market. The estimates for 2008 and 2009 presented to the Treasury are much lower than $20 \%$, and cast doubt on the credibility of the industry to advise the government on the size of the illicit market.

Illicit tobacco trade is a problem and should be taken seriously. In fact, the South African Revenue Services, together with TISA, the South African Police Services, the National Prosecuting Authority and other law enforcement agencies have been actively involved in efforts to reduce the illicit trade and there is evidence that this has paid off in the past 2 years. The adoption of the Protocol to Eliminate Illicit Trade in Tobacco Products at the November 2012 Conference of the Parties to the WHO-FCTC in Seoul is indicative of the seriousness of the problem. However, the industry's rhetoric about the magnitude of the problem should be examined critically. If previous estimates of the size of the illicit market proved to be hugely exaggerated, on what grounds are current estimates accurate?

The current study is a novel and inexpensive way of measuring trends in the illicit market and evaluating whether increases in illicit trade, real or imagined, have had negative fiscal consequences. The methodology is based crucially on the assumption that there exists a stable and predictable relationship between cigarette consumption and cigarette prices and income. As indicated above, numerous studies have demonstrated this relationship, and, as it turns out, in South Africa this relationship is particularly strong.

The paper comes to a nuanced conclusion with respect to changes in the illicit market. Excise revenues from cigarettes have, on average, been closer to budget and more predictable than revenues from beer and spirits. With the possible exception of 2000-2002, there is no evidence that there has been an increase in the illicit market until 2010. In 2010 there was a sharp increase in illicit trade and this has had a detrimental impact on excise revenues. The illicit market probably peaked in 2011, but has decreased substantially in 2012 . 
With minor modifications this methodology could be applied in other countries, especially where credible estimates of trends in the illicit market do not exist. What it does require, however, is a stable relationship between tobacco consumption and its determinants, relatively accurate time series data for the relevant variables, and an excise tax that is levied as a specific rather than an ad valorem tax.

\section{What this paper adds}

Statistics on the size of the illicit market are notoriously unreliable and prone to exaggeration by the tobacco industry. This paper investigates the claim that illicit trade in cigarettes has a negative impact on government revenue by comparing deviations from budgeted revenue to budget deviations of beer and spirits. The paper also investigates trends in the size of the illicit market by comparing the actual change in legal cigarette consumption to the predicted change in total cigarette consumption. This methodology can be applied, with few modifications, to other countries.

Acknowledgements Special thanks to Elaine Cleophas for collecting revenue and tax data. Thanks are also due to colleagues who reviewed earlier drafts: Evan Blecher, Grieve Chelwa, Jodie Posen, Hana Ross and Nicole Vellios. The author also thanks three referees of the journal.

Funding This work is part of the Economics of Tobacco Control Project and received funding from the American Cancer Society (contract number 10497). The findings, views and conclusions expressed here are those of the author and do not necessarily reflect the views of the ACS.

\section{Competing interests None.}

Provenance and peer review Not commissioned; externally peer reviewed.

Open Access This is an Open Access article distributed in accordance with the Creative Commons Attribution Non Commercial (CC BY-NC 3.0) license, which permits others to distribute, remix, adapt, build upon this work non-commercially, and license their derivative works on different terms, provided the original work is properly cited and the use is non-commercial. See: http://creativecommons.org/ licenses/by-nc/3.0/

\section{REFERENCES}

1 Van Walbeek C. The Economics of Tobacco Control in South Africa. Unpublished PhD thesis, Cape Town, South Africa: University of Cape Town, 2005.
2 Republic of South Africa. Budget review, Statistical Tables. Pretoria: Government Printer. Various years (1991-2013).

3 Joossens $\mathrm{L}$, Merriman $\mathrm{D}$, Ross $\mathrm{H}$, et al. The impact of eliminating the global illicit cigarette trade on health and revenue. Addiction 2010;105:1640-9.

4 Malan M, Leaver R. Political change in South Africa: New tobacco control and public health policies, in De Beyer and Waverley Brigden, Tobacco control policy: Strategies, successes \& setbacks 2003. Washington and Ottawa: World Bank and Research for International Tobacco Control, 2003.

5 National Treasury of South Africa. Personal communication with Cecil Morden, Chief Director of Economic Tax Analysis, 7 December 2012.

6 Carnot N, Koen V, Tissot B. Economic forecasting. Houndmills, Basingstoke: Palgrave Macmillan, 2005.

7 Hendry D, Ericson N eds. Understanding economic forecasts. Cambridge, Massachusetts: MIT Press, 2001.

8 Auditor-General. Report of the Auditor-General on the appropriation and miscellaneous accounts in respect of general affairs. Pretoria, Government Printer, various years.

9 South African Reserve Bank. Online statistical query. http://www.resbank.co.za/ Research/Statistics/Pages/OnlineDownloadFacility.aspx (accessed 22 May 2013).

10 Statistics South Africa. Consumer Price Index, various years. http://www.statssa.gov.za/ publications/statspastfuture.asp?PPN=P0141\&SCH=4575 (accessed 22 May 2013).

11 Fake cigarettes cost SA R2bn a year. http://www.iol.co.za/news/south-africa/r2bnlost-every-year-to-fake-cigarettes-1.289080\#.UZzXwal3BKY (accessed 22 May 2013).

12 Illicit cigarettes: Boom time for criminals. Financial Mail. 26 April 2013:50-1. http:// www.fm.co.za/fm/Features/2013/04/25/boom-times-for-criminals (accessed 22 May 2013)

13 International Agency for the Research on Cancer. Effectiveness of tax and price policies for tobacco control. IARC Handbooks of Cancer Prevention in Tobacco Control, Volume 14, 2011

14 Reekie W. Consumers' surplus and the demand for cigarettes. Managerial Decis Econ 1994:15:223-34

15 Van Walbeek C. Excise taxes on tobacco: How much scope does the government have? S Afr J Econ 1996:64:20-42.

16 Van der Merwe R, Annett N. Chapter 4: The effects of taxation on consumption in South Africa, in ETCSA, The economics of tobacco control in South Africa 1998 report submitted to the International Tobacco Initiative, School of Economics, University of Cape Town.

17 Economics of Tobacco Control in South Africa Project (Phase II). The tobacco epidemic can be reversed: Tobacco control in South Africa during the 1990s. Cape Town: Applied Fiscal Research Centre, 2003.

18 Boshoff W. Cigarette demand in South Africa over 1996-2006: the role of price, income and health awareness. S Afr J Econ 2008;76:118-31.

19 Joossens L, Raw M., From cigarette smuggling to illicit tobacco trade. Tob Control 2012; 21: 230-4.

20 Joossens $\mathrm{L}$, Merriman $\mathrm{D}$, Ross $\mathrm{H}$, et al. How eliminating the global illicit cigarette trade would raise revenues and save lives. Paris: International Union Against Tuberculosis and Lung Disease, 2009.

21 Tobacco Institute of South Africa. How we combat illicit trade. http://www. tobaccosa.co.za/browse.php?catid=101\&sub=120 (accessed 22 May 2013)

22 British American Tobacco, Presentation to National Treasury, June 2012. Unpublished. 